\title{
Effect of Age and Sex on some Physical and Chemical characteristics of Quail carcasses
}

\author{
Kareem Maulud Hamad \\ Deprt. of Animal Resources-College of Agriculture-University of Raparin-Sulaimani \\ Mohmmed Sulaiman Abdullah \\ Deprt. of Animal Resources-College of Agriculture-University of Salahaddin-Erbil
}

\begin{abstract}
The purpose of this study was to evaluate the effects of age and sex on live local desert line quail, dressed carcass yields, and meat chemical composition in whole meat , A total number of 60 quails at 6,9 and 12weeks, each groups contains 20 birds ( 10 males and 10 females), and measurements are taken for the following traits : live body weight, carcass weight, dress percentage and percentage of each part of. The experiment performed according to $3 \times 2$ factorial experiment in randomized complete design with three replicates. Results: the results showed that there were highly significant differences between males and females in body weight, dress percentage, thigh percentage, wing percentage , gizzard percentage and cooking loss, although Results revealed that significant $(P<0.05)$ increases in live body weight, carcass weight, dressing percentage, percentages of thigh , wings, neck, liver ,heart, gizzard, chemical meat composition were observed in addition of water holding capacity (WHC), cooking loss were also increased as the birds get older.
\end{abstract}

Keywords : age, sex ; live weight ; carcass ; meat composition ;water holding capacity ; cooking loss

\section{INTRODUCTION}

Japanese quail is the smallest avian specie which can be easily handled, and largely farmed for egg and meat production (Minvielle et al., 1998). Raising quails for meat production is a genuine alternative to other animals raised as sources of animal protein (Faitarone et al., 2005). The quality of poultry meat may be affected by numerous factors associated with either the animal or its environment, such as age, sex, breed, species, rearing and feeding system, handling and slaughtering conditions (Berri et al., 2004).

There are many studies conducted in Iraq about viability and production performance of Japanese quail in the natural environment exhibited high adaptation for Iraqi conditions( Hassan ,2013). Although Hassan et al,2013 reported in their study that the age has highly significant effect in body weight, carcass weight, intestine length, also there was significant effect of age in thigh weight, and the sex has significant effect in body weight, dress percentage., intestine length, liver weight percentage.

Daikwo et al.2013 reported $72.36 \%$ an average dressing percentage in Japanese quail, and the measurements of carcass weight, breast weight, thigh weight, liver weight, heart weight and gizzard weight, their records were $90.01,29.73,6.44,2.39,1.15$ and 2.67 respectively.

Selim, et al., (2006), studied the effect of sex on Live Body Weight (LBW), slaughter weight and carcass weight and reported higher carcass characteristics in female than males. Some of the estimated genetic parameters for different traits of Japanese quails were reported by several researchers. Seizai et al., (2010), discovered sex had significant effect on carcass weight and females had higher carcass weight than the males $(\mathrm{p}<0.01)$. Carcass yield were found $75.47 \%$ for females and $73.4 \%$ for males. Altinel and Cerit, (1998), reported that average live body weight at the end of 6 weeks period was $159.01 \mathrm{~g}$ in males and $179.9 \mathrm{~g}$ in females .

The Japanese quail meat deboned manually is proved to contain $72.5-75.1 \%$ water, $20-23.4 \%$ protein, $1.0-3.4 \%$ lipids and $1.2-1.6 \%$ mineral substances. The one deboned mechanically, however, contains $17 \%$ protein, $10 \%$ fat and $2.6 \%$ minerals. In comparative studies on physiochemical properties of ducks, broil chicken, and quail meat, it was proved that the quail meat contained the lowest-calorie meat with the highest protein level (Ribarski and Genchev, 2013).

WHC is the highest immediately after slaughtering, prior to rigor mortis occurrence. After rigor mortis resolution, the WHC of meat was reduced. The good water holding capacity of breast and leg meat guarant excellent technological properties of meat. The lower WHC of the pectoral muscle in female quails could be related to slightly lower breast meat $\mathrm{pH}$ values. Poultry meats with lower $\mathrm{pH}$ are characterized with lower water holding capacity (Genchev et al., 2010).

The present study investigated the influence of varying lengths of starving periods on quality attributes of chicken meat and to define the best FW period and their effect on meat chemical composition . 


\section{MATERIALS AND METHODS}

This experiment was conducted in the quail breeding house of Zharawa private Quail breeding project, A total of 60local desert line quails at ages 6,9 and 12 weeks. The birds were bred in cages under controlled environmental conditions and provided with food and fresh clean water was offered ad libitum .

Each live bird was weighed and slaughtered to ensure complete bleeding. The feathers, neck, edible and inedible viscera (head, preen, gland, feet, lungs, gizzard and liver) were removed. Finally carcass was weighed to observe the carcass yield.

\section{Analysis of carcass composition}

Breast, thigh, back, Wing and neck parts of carcass were weighed separately to evaluate the carcass composition of quail bird.

\section{Physical analysis}

Water holding capacity, $\mathrm{pH}$ value, cooking loss were determined using protocols reported by Wardlaw et al. (1973); Ockerman (1985); Kondaiahet al. (1985) and Sen et al. (2004), respectively.

\section{Chemical analysis}

Protein (Kjeldhal), fat (Ether extraction) and ash contents of quail meat were determined according to the methods described by Association of Official Analytical Chemists (AOAC, 2000).

All data were analyzed by using the General Linear Models procedure (SAS, 1996) to study the effect of treatments and strains according to Factorial $-\mathrm{CRD}(4 * 2)$ experiment ( two way with interaction), significant differences among the means of the levels of each factor were determined by Duncan multiple range test .

\section{RESULTS AND DISSCUSION}

Table 1 The results show significant difference $(\mathrm{P}<0.05)$ in means of the Slaughter weight $(\mathrm{g})$, at the age of 6,9 and 12 weeks, $172.50 \mathrm{~g}, 169.83 \mathrm{~g}$ and $193.50 \mathrm{~g}$ respectively. Quails will attain the best slaughter weight $(169.0 \mathrm{~g})$ at the age of 12 weeks under a good feeding management. According to Wilkkanowska et al.2011 quail carcass yield characteristics are affected by age, the body weight increases with age, older birds have higher carcass weight compared to young birds. The cold carcasses weight and dressing percentage at 6,9 and 12 weeks were $(100.33,104.91$ and $116.41 \mathrm{~g}),(58.44,61.93$ and $60.91 \%)$ respectively.. This reveals that at week 12 is the best age at which greater carcass yield can be realized, cold carcass weight are higher in week 12 compared to the weights at weeks 6 and 9

Table 1 the main effect, sex, was significant $(\mathrm{P}<0.05)$ on quail live body weight and dressing percentages . Female quail birds had a higher mean value than the male counterpart $(191.11 \mathrm{~g}$ Vs $166.11 \mathrm{~g})$. These results concur with studies by Simeon , 2015 which reported that the Japanese quail is a sexually dimorphic bird with females having a larger body size than males unlike other poultry species. The quail birds showed differences in growth pattern between sexes, the males displayed slightly higher dressing percentages than the females (63.44\% Vs. 58.89\%) respectively. This difference could be associated with the aggressiveness of males over the females especially when reared together; the females are disadvantaged during feeding and watering. Musa et al , 2006 However, the growth pattern variation was different with the results by in which female quails produced higher carcass yields than male quails, the smaller body weight and decrease in live weight in male quails was associated with higher metabolic rates and hormonal change respectively.

In Table ( 2 ) showed none significant differences in PH at the ages 6,9 and 12weeks and also between males and females . this due to glycogen is static all ages .Although revealed significant difference in water holding capacity and cooking loss at ages 6,9 and 12 weeks this due to increase protein percentage by ages lead to decrease free water according to Anadon, 2012 . As well as there are significant difference in cooking loss at ages 6,9 and 12 weeks this due to increase fat percentage lead to loss water during cooking 
Table 1. effect age and sex on local quail live body weight, Carcass weight and dressing percentage .

\begin{tabular}{|c|c|c|c|c|}
\hline Sex & Age & Live weight & Carcass Weight & Dressing \% \\
\hline \multirow{3}{*}{ Male } & 6 & $155 \mathrm{~d} \pm 0.966$ & $95.33 \mathrm{c} \pm 1.68$ & $61.49 \mathrm{~b} \pm 0.008$ \\
\hline & 9 & $165 c \pm 4.74$ & $110.33 \mathrm{ab} \pm 4.65$ & $66.56 \mathrm{a} \pm 0.011$ \\
\hline & 12 & $178 b c \pm 1.05$ & $112.33 \mathrm{ab} \pm 0.76$ & $63.01 \mathrm{~b} \pm 0.007$ \\
\hline \multirow{3}{*}{ Female } & 6 & $190 \mathrm{~b} \pm 4.66$ & $105.03 b c \pm 4.56$ & $55.31 \mathrm{c} \pm 0.011$ \\
\hline & 9 & $174.66 \mathrm{c} \pm 8.90$ & $99.83 \mathrm{c} \pm 3.57$ & $57.41 \mathrm{c} \pm 0.011$ \\
\hline & 12 & $208.66 \mathrm{a} \pm 6.06$ & $120.5 \mathrm{a} \pm 4.00$ & $57.71 \mathrm{c} \pm 0.005$ \\
\hline \multirow{3}{*}{$\begin{array}{l}\text { Age } \\
\text { effect }\end{array}$} & 6 & $172.50 \mathrm{~b} \pm 5.74$ & $100.33 \mathrm{~b} \pm 2.76$ & $58.41 \mathrm{~b} \pm 0.011$ \\
\hline & 9 & $169.83 b \pm 5.02$ & $104.917 \mathrm{~b} \pm 3.192$ & $61.93 a+5.025$ \\
\hline & 12 & $193.50 \mathrm{a} \pm 5.43$ & $116.41 \mathrm{a} \pm 2.30$ & $60.34 \mathrm{a} \pm 0.009$ \\
\hline \multirow{2}{*}{$\begin{array}{l}\text { Sex } \\
\text { effect }\end{array}$} & Male & $166.11 \mathrm{~b} \pm 2.789$ & $105.89 \mathrm{a} \pm 2.406$ & $63.44 \mathrm{a} \pm 0.007$ \\
\hline & Female & $191.11 \mathrm{a} \pm 4.980$ & $108.55 \mathrm{a} \pm 3.06$ & $58.89 \mathrm{~b} \pm 0.005$ \\
\hline
\end{tabular}

Different letters in the same column indicate a statistical difference $(\mathrm{P} \leq 0.05)$.

Table 2. effect of Age and Sex on PH, Water Holding Capacity and Cooking Loss.

\begin{tabular}{|c|c|c|c|c|}
\hline Sex & Age/ Weeks & $\mathrm{PH}$ & Water Holding Capacity & Cooking Loss \\
\hline \multirow{4}{*}{ Male } & 6 & $6.10 \pm 0.06$ & $3.16 \mathrm{c} \pm 0.55$ & $15.91 \mathrm{e} \pm 0.041$ \\
\hline & 9 & $6.07 \pm 0.02$ & $3.58 \mathrm{bc} \pm 0.34$ & $21.66 \mathrm{a} \pm 0.00$ \\
\hline & 12 & $6.17 \pm 0.033$ & $4.67 \mathrm{a} \pm 0.10$ & $20.76 \mathrm{~b} \pm 0.06$ \\
\hline & & & & \\
\hline \multirow[b]{3}{*}{ Femal } & 6 & $6.02 \pm 0.025$ & $2.16 \mathrm{~d} \pm 0.105$ & $14.44 \mathrm{f} \pm 0.000$ \\
\hline & 9 & $6.32 \pm 0.20$ & $4.21 \mathrm{ab} \pm 0.093$ & $19.14 \mathrm{~d} \pm 0.000$ \\
\hline & 12 & $6.22 \pm 0.007$ & $4.32 \mathrm{ab} \pm 0.37$ & $19.74 \mathrm{c} \pm 0.05$ \\
\hline \multirow{3}{*}{$\begin{array}{l}\text { Age } \\
\text { effect }\end{array}$} & 6 & $6.06 \pm 0.35$ & $2.66 \mathrm{~b} \pm 0.309$ & $15.17 \mathrm{c} \pm 0.22$ \\
\hline & 9 & $6.20 \pm 0.107$ & $3.90 \mathrm{a} \pm 0.19$ & $20.25 b \pm 0.38$ \\
\hline & 12 & $6.20 \pm 0.018$ & $4.50 \mathrm{a} \pm 0.19$ & $20.41 \mathrm{a} \pm 0.15$ \\
\hline \multirow{2}{*}{$\begin{array}{l}\text { Sex } \\
\text { effect }\end{array}$} & Male & $6.11 \pm 0.02$ & $3.80 \pm 0.25$ & $19.44 \mathrm{a} \pm 0.61$ \\
\hline & Female & $6.18 \pm 0.07$ & $3.57 \pm 0.27$ & $17.77 \mathrm{~b} \pm 0.57$ \\
\hline
\end{tabular}

Different letters in the same column indicate a statistical difference $(\mathrm{P} \leq 0.05)$.

In table( 3 ). Showed no significant differences among treatments in some part of carcass percentage such as breast $\%$, back \% and heart \%but there was significant differences $(\mathrm{P}<0.05)$ in liver $\%$, wings $\%$, neck \% , thigh $\%$ and gizzard $\%$ at ages 6,9 and 12 weeks These results are in agreement with those of Maurice, 2006 who suggested the appropriate age to slaughter the quail bird is between 5 to 6 weeks of age. Other parameters such as liver \% and gizzard \% showed significant differences $(\mathrm{P}<0.05$ in relation to slaughter weight while the Wings \% and Thighs (\%) had significant differences in relation to the cold carcass weight,(\%) cold carcass, and also there were no significant differences between males and females in some parts of carcass percentage such as breast $\%$, back $\%$, liver $\%$ and heart $\%$ this agree with Walita et al, 2017 showed no significant between males and females in same traits however, the significant differences was found in thigh $\%$, wings $\%$,neck \% and gizzard $\%$. 
In table( 4). Showed significant differences in meat chemical composition at ages 6,9 and 12 weeks such as moisture $\%$, protein $\%$, fat $\%$ and ash $\%$ in whole meat, also there were significant difference in protein $\%$ between males and females .

The meat of young quail showed higher protein and moisture contents and lower fat content than spent quail meat. Research on animal meat has indicated that an increase in age is accompanied by an increase in intramuscular fat (Lawrie, 1991). According Baker and Derfler, 1981 showed that decrease moisture as birds get order and increase dry matter.

Table 3. effect of Age and Sex on percentage of each part of carcass ( \%).

\begin{tabular}{|c|c|c|c|c|c|c|c|c|c|}
\hline Sex & Age & Breast \% & Thigh $\%$ & Wings $\%$ & Back \% & Neck \% & Liver $\%$ & Heart $\%$ & Gizzard \% \\
\hline \multirow{3}{*}{ Male } & 6 & $36.92 \mathrm{abc} \pm 0.023$ & $23.54 \mathrm{ab} \pm 0.013$ & $5.52 \mathrm{~d} \pm 0.003$ & $18.66 \mathrm{a} \pm 0.015$ & $4.54 c \pm 0.001$ & $4.57 \mathrm{~b} \pm 0.003$ & $2.00 \mathrm{e} \pm 0.0002$ & $3.13 \mathrm{~d} \pm 0.0005$ \\
\hline & 9 & $34.33 \mathrm{c} \pm 0.004$ & $21.22 \mathrm{bc} \pm 0.002$ & $5.24 \mathrm{e} \pm 0.005$ & $16.43 \mathrm{ab} \pm 0.01$ & $4.59 \mathrm{c} \pm 0.004$ & $3.66 \mathrm{~d} \pm 0.001$ & $2.17 \mathrm{~d} \pm 0.001$ & $3.63 \mathrm{a} \pm 0.0006$ \\
\hline & 12 & $35.91 b c \pm 0.004$ & $25.49 \mathrm{a} \pm 0.010$ & $6.52 \mathrm{c} \pm 0.001$ & $18.74 \mathrm{a} \pm 0.01$ & $5.63 a \pm 0.001$ & $3.26 \mathrm{f} \pm 0.001$ & $2.51 \mathrm{a} \pm 0.0007$ & $3.25 \mathrm{c} \pm 0.001$ \\
\hline \multirow{3}{*}{ Female } & 6 & $37.98 \mathrm{ab} \pm 0.019$ & $22.88 \mathrm{abc} \pm 0.005$ & $5.63 d \pm 0.003$ & $17.19 \mathrm{ab} \pm 0.021$ & $4.15 \mathrm{e} \pm 0.003$ & $3.47 \mathrm{e} \pm 0.001$ & $2.05 \mathrm{f} \pm 0.0004$ & $2.87 \mathrm{f} \pm 0.001$ \\
\hline & 9 & $39.31 \mathrm{a} \pm 0.01$ & $20.26 c \pm 0.012$ & $7.93 \mathrm{~b} \pm 0.004$ & $18.32 \mathrm{a} \pm 0.007$ & $4.29 \mathrm{~d} \pm 0.003$ & $4.73 a \pm 0.003$ & $2.39 \mathrm{~b} \pm 0.0014$ & $3.47 \mathrm{~b} \pm 0.002$ \\
\hline & 12 & $34.57 \mathrm{c} \pm 0.004$ & $21.39 \mathrm{bc} \pm 0.005$ & $8.26 \mathrm{a} \pm 0.004$ & $14.63 \mathrm{~b} \pm 0.006$ & $4.79 b \pm 0.006$ & $3.75 \mathrm{c} \pm 0.001$ & $2.34 \mathrm{c} \pm 0.0001$ & $2.90 \mathrm{e} \pm 0.0009$ \\
\hline \multirow{3}{*}{$\begin{array}{l}\text { Age } \\
\text { effect }\end{array}$} & 6 & $37.57 \pm 0.014$ & $23.21 \mathrm{a} \pm 0.006$ & $5.62 \mathrm{~b} \pm 0.002$ & $17.90 \pm 0.012$ & $4.30 \mathrm{~b} \pm 0.002$ & $4.01 \mathrm{a} \pm 0.002$ & $2.01 \mathrm{~b} \pm 0.002$ & $3.01 \mathrm{~b} \pm 0.007$ \\
\hline & 9 & $36.32 \pm 0.009$ & $20.74 b \pm 0.006$ & $6.53 a \pm 0.005$ & $17.31 \pm 0.007$ & $4.40 \mathrm{ab} \pm 0.002$ & $4.21 \mathrm{a} \pm 0.002$ & $2.20 \mathrm{a} \pm 0.001$ & $3.50 \mathrm{a} \pm 0.001$ \\
\hline & 12 & $35.22 \pm 0.003$ & $23.44 \mathrm{a} \pm 0.008$ & $7.31 \mathrm{a} \pm 0.0003$ & $16.67 \pm 0.01$ & $5.20 \mathrm{a} \pm 0.003$ & $3.50 \mathrm{~b} \pm 0.001$ & $2.40 \mathrm{a} \pm 0.0004$ & $3.02 \mathrm{~b} \pm 0.001$ \\
\hline \multirow{2}{*}{$\begin{array}{c}\text { Sex } \\
\text { effect }\end{array}$} & Male & $35.44 \pm 0.0008$ & $23.40 \mathrm{a} \pm 0.06$ & $5.71 \mathrm{~b} \pm 0.002$ & $17.90 \pm 0.007$ & $4.90 \mathrm{~b} \pm 0.002$ & $3.80 \pm 0.0001$ & $2.20 \pm 0.0007$ & $3.33 \mathrm{a} \pm 0.007$ \\
\hline & Female & $32.38 \pm 0.0007$ & $21.51 \mathrm{~b} \pm 0.005$ & $7.22 \mathrm{a} \pm 0.003$ & $16.78 \pm 0.008$ & $4.48 \pm 0.003$ & $3.91 \pm 0.002$ & $2.30 \pm 0.0006$ & $3.06 \mathrm{~b} \pm 0.001$ \\
\hline
\end{tabular}

Different letters in the same column indicate a statistical difference $(\mathrm{P} \leq 0.05)$.

Table 4. Effect of Age and Sex on meat chemical composition ( \%)

\begin{tabular}{|c|c|c|c|c|c|}
\hline \multirow{3}{*}{ Sex } & \multirow{2}{*}{$\begin{array}{c}\text { Age/ } \\
\text { Weeks }\end{array}$} & \multicolumn{4}{|c|}{ Meat Chemical Composition } \\
\cline { 3 - 6 } & & Moisture \% & protein $\%$ & Fat \% & Ash \% \\
\hline \multirow{3}{*}{ Male } & 6 & $72.25 \mathrm{a} \pm 0.06$ & $22.73 \mathrm{c} \pm 0.10$ & $1.54 \mathrm{~b} \pm 0.037$ & $1.46 \mathrm{ab} \pm 0.059$ \\
\cline { 2 - 6 } & 9 & $70.39 \mathrm{ab} \pm 0.55$ & $23.71 \mathrm{bc} \pm 0.59$ & $2.31 \mathrm{~b} \pm 0.08$ & $1.57 \mathrm{a} \pm 0.11$ \\
\cline { 2 - 6 } & 12 & $66.76 \mathrm{c} \pm 1.45$ & $24.90 \mathrm{ab} \pm 0.46$ & $2.87 \mathrm{a} \pm 1.004$ & $1.55 \mathrm{a} \pm 0.012$ \\
\hline \multirow{3}{*}{ Female } & 6 & $68.22 \mathrm{bc} \pm 0.54$ & $25.45 \mathrm{a} \pm 0.27$ & $2.77 \mathrm{ab} \pm 0.21$ & $1.54 \mathrm{ab} \pm 0.06$ \\
\cline { 2 - 6 } & 9 & $70.73 \mathrm{ab} \pm 0.81$ & $23.59 \mathrm{c} \pm 0.51$ & $2.39 \mathrm{~b} \pm 0.31$ & $1.28 \mathrm{~b} \pm 0.006$ \\
\cline { 2 - 6 } & 12 & $69.13 \mathrm{~b} \pm 0.39$ & $25.16 \mathrm{a} \pm 0.06$ & $2.00 \mathrm{~b} \pm 0.22$ & $1.69 \mathrm{a} \pm 0.15$ \\
\hline \multirow{3}{*}{$\begin{array}{c}\text { Age } \\
\text { effect }\end{array}$} & 6 & $70.23 \mathrm{a} \pm 0.661$ & $24.09 \mathrm{~b} \pm 0.43$ & $2.15 \mathrm{~b} \pm 0.21$ & $1.50 \mathrm{ab} \pm 0.041$ \\
\cline { 2 - 6 } & 9 & $70.56 \mathrm{a} \pm 0.47$ & $23.65 \mathrm{~b} \pm 0.37$ & $2.35 \mathrm{~b} \pm 0.156$ & $1.42 \mathrm{~b} \pm 0.07$ \\
\hline \multirow{2}{*}{$\begin{array}{c}\text { Sex } \\
\text { effect }\end{array}$} & Male & $67.94 \mathrm{~b} \pm 0.801$ & $25.03 \mathrm{a} \pm 0.22$ & $3.39 \mathrm{a} \pm 0.64$ & $1.621 \mathrm{a} \pm 0.07$ \\
\cline { 2 - 6 } & Female & $69.33 \pm 0.69$ & $24.74 \mathrm{a} \pm 0.41$ & $2.39 \pm 0.157$ & $1.50 \pm 0.06$ \\
\hline
\end{tabular}

Different letters in the same column indicate a statistical difference $(\mathrm{P} \leq 0.05)$.

\section{CONCLUSIONS}

Carcass yield of Japanese quail is affected by several factors such as age and sex Female quail birds registered higher carcass traits than the male counter parts. Female quail birds have higher slaughter weight as compared to the males. The study concludes that the optimal age to slaughter quail birds is around 12 weeks. Higher carcass yields as well as dressing percentages are realized at this age.

\section{REFERENCES}

[1] Altinel, A., Cerit, H.(1998). Genetic and phenotypic parameters of various traits in the Japanese quail (Coturnix coturnix japonica). Vet. Fakult. Derg. Istambul. 24, 111-136.

[2] Anadon , H.L.S.(2002).Biological, Nutritional, and Processing factors affecting breast meat quality of broilers, Ph.D. thesis , University of Virginia, Blacksburg, Virginia

[3] AOAC.(2000).Official Methods of Analysis 17lh Ed. Association of Official Analytical Chemists, Arlington, V.A.

[4] Berri, C., 2004. Breeding and quality of poultry. In, Mead GC (Ed): Poultry Meat Processing and Quality CRC Press, Cambridge., 2133.

[5] Baker,R.C., andJ.M.Drafler,1981.The development of a poultry ham product. Poultry Sci., 60:1429-1435.

[6] Daikwo, S. I., O. M. Momoh and N. I. Dim. 2013. Heritability Estimates of, Genetic and Phenotypic Correlations among Some Selected Carcass Traits of Climate. Journal of Biology, Agriculture and Healthcare, Vol.3, No.5: $60-65$. 
[7] Faitore, A.B.G., Pavan, A.C., Mori, C., Batista, L.S., Oliveira, R.P., Garcia, E.A., Pizzolante, C.C., Mendes, A.A., Sherer, M.R., 2005. Economic traits and performance of italian quails reared at different cage stocking densities. Revista Brasileira de Ciências Avícolas., 7(1),19-22.

[8] Genchev A, Ribarski S, Zhelyazkov G. (2010). Physicochemical and technological properties of Japanese quail meat. Trakia Journal of Sciences, 8 (4): 86-94.

[9] Hassan, K. H. 2013. Evaluation of productive performance of Japanese quail in summer of Iraq. Diyala Agricultural Science Journal, 5 (2): $69-80$

[10] Hassan, K. H., A. A. Ahmad, T. A. Dawood, and N. K. Fadi. 2013 Study of dress percentage and relative weights of carcass parts in various ages of Japanese quail in Iraq. Diyala Agricultural Science Journal, 5 (2):92-103.

[11] Kondaiah, N., A. S. R. Anjaneyulu, K. V. Rao, N. Sharma and H. B. Joshi. 1985. Effect of salt and phosphate on the quality of buffalo and goat meats. Meat Sci., 15: 183-192.

[12] Lawrie, R. A. 1991. Meat Science, 5th edn. Oxford Pergamon Press.

[13] Minvielle, F., 1998. Genetic and breeding of Japanese quail for production around the world. Proceedings 6th Asian Pacific Poultry Congress Nagoya, Japan.

[14] Maurice Randal. Raising Japanese Quail. 2006.

[15] Ockerman, H. W. (1985). Quality control of post-mortem muscles tissue (13th Ed). The Ohio State University, Colombus.

[16] Ribarski S, Genchev A. (2013). Effect of breed on meat quality in Japanese Quails (Coturnix Coturnix Japonica). Trakia Journal of Sciences, 11(2): 181-188

[17] SAS.1996. SASuser guide : Static's (version- 5 ed.) SAS inst.Inc.Cary. NC.USA

[18] Sen, A. R., A. Santra and S. A. Karim. (2004). Carcass yield, composition and meat quality attributes of sheep and goat under semiarid conditions. Meat Sci., 66: 757-763.

[19] Simeon OO. Carcass characteristics of coturnix quail as affected by sexand Housing System. International Journal of Agriculture, Forestry and Fisheries. 2015;3(3):76-79.

[20] Selim, K., Ibarhim, S., Ozge, Y., 2006. Effect of separate and mixed rearing according to sex on tattering performance and carcass characteristics in Japanese quails. (Coturnix coturnix Japonica). Arch Tierz. Dummerstort. 49(6), 607-614.

[21] Seizai, A., Kemal, K., Askin, G., Taki, K., Murat, S.B., 2010. Determination of body weight and some carcass trait in Japanese quail. (Coturnix coturnix Japonica) of different lines Kafkas Univ. Vet. Tak. Derg. 16(2), 277-280.

[22] Wardlaw, F. B., L. H. McCaskill and J. C. Acton. (1973). Effect of postmortem muscle changes on poultry meat loaf properties. J. Food Sci., 38: 421-423.

[23] Wilkkanowska A, Kokoszyński D.(2011). Comparison of Slaughter Value in Pharaoh Quail of ages. Journal of central European Agriculture.;12(1):145-154.

[24] Walita Kamija Z , Jonathan Tanganyika, Steven R Mussah .(2017). Effect of Sex, type of feed and age at slaughter on carcass yield characteristics of japanese quails (cortunix japonica) in Malawi. Int J Avian \& Wildlife Biol.;2(2):50.53. 